\title{
Pharmacognostical studies of important arid zone plants
}

\author{
Satish C. Jain, ${ }^{*, 1}$ B. Pancholi, ${ }^{1}$ R. Singh, ${ }^{1}$ R. Jain ${ }^{2}$ \\ ${ }^{1}$ Medicinal Plants \& Biotechnology Laboratory, Department of Botany, University of Rajasthan, Jaipur-302004, India, \\ ${ }^{2}$ Department of Chemistry, University of Rajasthan, Jaipur-302004, India.
}

\begin{abstract}
RESUMO: "Estudos farmacognósticos de plantas importantes de zonas áridas". A zona árida de Rajasthan, Índia, é importante pela grande diversidade e especificidade de plantas endêmicas de importância econômica e medicinal. Destas, três plantas de zonas áridas, Gisekia pharnaceoides L., Gisekiaceae, Sericostoma pauciflorum Stocks ex Wight, Boraginaceae, e Trianthema decandra L., Aizoaceae, que são tradicionalmente utilizados para diversas doenças (hepatite, asma, icterícia, infecções da pele etc.), foram selecionados para o estudo. Neste trabalho trabalho, a avaliação farmacognóstica detalhada destas espécies, através de estudo morfoanatômico, determinações físico-químicas e parâmetros fitoquímicos, foram realizados. As características morfológicas podem ser utilizados para rápida identificação das drogas, particularmente no caso de materiais em pó, e possivelmente ajudar a diferenciar a droga de outras espécies.
\end{abstract}

Unitermos: Plantas de zona árida, Gisekia pharnaceoides, Sericostoma pauciflorum, Trianthema decandra, avaliação farmacognóstica.

\begin{abstract}
Arid zone of Rajasthan, India, has its own importance, great diversity and specific characteristic with respect to endemic and large number of plants of economic importance and medicinal use. Out of these, three arid zone plants Gisekia pharnaceoides L., Gisekiaceae, Sericostoma pauciflorum Stocks ex Wight, Boraginaceae, and Trianthema decandra L., Aizoaceae, which are traditionally used for different ailments (hepatitis, asthma, jaundice, skin-infections etc.) have been selected for the study. In the present paper, detailed pharmacognostical evaluation of these plant species using microscopy, standard physicochemical determinations and authentic phytochemical parameters has been carried out. Later on, these morphological characteristics could be used for rapid identification of the drugs, particularly in case of powdered materials, and may possibly help to differentiate the drug from its other species.
\end{abstract}

Keywords: Arid zone plants, Gisekia pharnaceoides, Sericostoma pauciflorum, Trianthema decandra, pharmacognostical evaluation.

\section{INTRODUCTION}

Arid zone is characterized by extremes of temperature, severe drought accompanied by high wind velocity, low relative humidity, evaporation far exceeding precipitation and too scanty rain fall to support any appreciable vegetation. In general, the vegetation of arid zone is sparse. Plants with only xerophytic adaptations are able to establish themselves. In the process of protection, they accumulate some important secondary metabolites which have medicinal importance. In the study, three important medicinal plants of arid zone viz. Gisekia pharnaceoides L., Gisekiaceae (Vern.- Sarelimorang), Sericostoma pauciflorum Stocks ex Wight, Boraginaceae (Vern.-Karvas) and Trianthema decandra L., Aizoaceae (Vern.-Gadabani), have been studied for their pharmacognostical markers.

Whole plant of $G$. pharnaceoides is used as aperient, purgative, anthelmintic, in female diseases, defective semen, destroys fat and in malfunctioning of sex organs and plant extract used for killing roundworms (Bakshi et al., 2001). Traditionally, the plant is used on swellings. Its powder is also mixed with other herbs as poultices for sores on cattle. Extracts of the plant is used in painting and decoration of hands and the sole of feet by women due to the reddish-wine tinge color (Amico, 1977).

Phytochemical studies revealed the presence of myristone, triacontane, $\beta$-sitosterol, tetracosanol, dotriacontane and acetyl glycosides (Iyer et al., 1972), tannins, alkaloids, resins, cardiac glycosides, flavonoids and carbohydrates (Musa et al., 2006).

S. pauciflorum used in dehydration and acidity. Phytochemically, fernane, hopane and other type of triterpenoids were isolated from the plant (Afza et al., 1992; Ayatollahi et al., 1991; 1992a,b). 
Roots, root bark and leaves of $T$. decandra act as aperients, laxative and useful in treatment of hepatitis, asthma, suppression of the menses and in inflammation of testicles. Roots ground up with milk and given internally considered specific for orchitis; juice of leaves dropped into the nostrils to relieve one-sided headache (Chopra et al., 1956).

In view of the diverse medicinal importance of the selected arid zone plants and in order to ensure the quality, especially in terms of adulteration, substitution and identification of the plant material, the present investigation was carried out. The study includes pharmacognostical evaluation by determination of physicochemical constants and phytochemical screening of these three traditionally used medicinal plants of arid zone of Rajasthan, India.

\section{MATERIAL AND METHODS}

The selected plants were collected from the arid zone of Rajasthan, during 2007-2008. The botanical identity was confirmed by Herbarium, Department of Botany, University of Rajasthan, Jaipur. Voucher specimens of these plants, G. pharnaceoides (64), S. pauciflorum (110) and $T$. decandra (132) has been deposited at the Herbarium and laboratory for further reference.

\section{Chemical and instruments}

Microphotographs were taken using Nikon Eclipse E-600 microscope, with photographic attachmentNikon Poolpix 5400. Staining dyes such as eosin and fast green and other staining equipments were purchased from Hi Media Chemicals Ltd. Mumbai, India.

\section{Macroscopic analysis}

Stems of the three selected plants were used for their microscopical (Brain \& Turner, 1975), microscopical (Johanson, 1940) and micropowder (Brain \& Turner, 1975; Kokate, 1986) analyzed by different standard protocols. Alcohol (ASE) and water-soluble extractives (WSE), total ash (TA), acid insoluble ash (AIA) and loss on drying (LOD) of whole plants were determined by the procedures given in the Indian Pharmacopoeia (1996) and under the WHO guidelines on quality control methods for medicinal plant (1992). Fluorescence analysis was carried out by following established protocols (Chase \& Pratt, 1949; Kokoski et al., 1958).

\section{Preliminary analysis}

Qualitative phytochemical estimation was carried out by using standard procedures (Kokate, 1986; Harborne, 1998).

\section{RESULTS AND DISCUSSION}

\section{Macroscopic characters}

G. pharnaceoides is a glabrous, succulent, prostrate or ascending herb. Stem up to $6 \mathrm{dm}$, pale colored with short, decurrent ridges down the nodes. Leaves 10-50 $\times 4-8 \mathrm{~mm}$, mostly opposite, sessile or obscurely petiolate; blade linear or linear-oblanceolate in shape. Inflorescence sessile or pedenculate, umbelliform, 10-30 flowered cymes; peduncles usually simple or cymosely branched, up to $30 \mathrm{~mm}$ long, flowers are hermaphrodite, often pink to greenish white; sepals are 5, 1-3 cm long, fruiting calyx with membranous margins, cucullate; stamens 5 , filaments dilated at base, anthers pink; carpels surrounded with sepals; seeds solitary, black and rounded on back.

S. pauciflorum is a small, straggling shrub, 1-5 $\mathrm{dm}$ in height. Roots are woody and blackish in color. Stem woody at the base, bark whitish, cracked; branches many, rigid, covered with white hairs. Leaves 6-30 $\times 2-4 \mathrm{~mm}$, opposite or alternate sessile, linear, usually curved, clothed with stiff hairs from bulbous base. Inflorescence 2-5 flowered, leaf-opposed, terminal; calyx more then $3 \mathrm{~mm}$ long enlarging in fruits, hairy outside; corolla white, $4 \mathrm{~mm}$ long; ovary 4 lobed; style $1 \mathrm{~mm}$ long, stigma capitate; fruit nutlets $2.5 \mathrm{~mm}$ long, usually two with short sub-lateral stalk, rounded and granular at the back, accuminate at the apex included in the persistent calyx.

T. decandra is a somewhat succulent, subglabrous, annual herb. Stem spreading, procumbent or prostate, with a decurrent line of hairs from inter petiolar stipules to the nodes below, glabrescent, often alternatively branched by the development of auxiliary buds, subtended by the small leaf of nodal pair. Leaves 10-40 $\times 5-35 \mathrm{~mm}$ in size, opposite, one pair smaller then the other, 2 to $4 \mathrm{~cm}$ in length, leathery; the smaller leaves are narrow, oblong tapering to the base, rounded to apiculate at the apex, 10.2 to $6 \mathrm{~mm}$ in size, long petiolated, dilated into membranous pouch at the base claspering in the stem specially those of the stem especially those of smaller leaves, slightly hairy; flowers small, solitary sessile white concealed by the pouch of the petiole, calyx tube scarious thin, stamens 10-15, ovary superior sessile, style single pappillose. Fruit capsulate $3.5 \mathrm{~mm}$ long beak like; seeds 2 to 3 reniform blackish.

\section{Microscopic characters}

G. pharnaceoides epidermal peel consists of one layer of cells with unicellular trichomes and collenchymatous thickening (Figure 1A). Stem anatomical section is hexagonal in outline with epidermal bulging. Epidermal cells are almost square in outline, with some as hairs. The peripheral layer consisted of 1-2 layers of prenchymatous cells. In younger stem pith is intact and parenchymatous in nature (Figure 1B). Oval shaped crystals 
were seen on cortical region. The inner cortex entirely made up of parenchyma cells containing chloroplasts. Internally to the cortex is a layer of periclinally elongated cells, referred as endodermis or "starch sheath". Pericycle is not very prominent. Primary phloem was crushed forming small patches of discontinuous ring; secondary phloem formed a complete ring. Metaxylem is a complete cylinder having parenchymatous rays with protoxylem groups near the pith. Vascular bundles conjoint, collateral, endarch and open. In older stem pith crushed and formed a hollow cavity (Figure 1C).

In S. pauciflorum, epidermal peel with multicellular epidermal hairs having cluster of cells near the origin were observed. Epidermal cells were unicellular (Figure 2A). TS was almost circular in outline with thick walled multilayered cells, outer face cuticularised, cells almost rectangular in shape. Cortex is many layered deep, differentiated into outer collenchyma and inner chlorenchyma; collenchyma is four five cells deep, cells polygonal thickened at the contact with the neighboring cells; chlorenchyma extended up to endodermis, many cells deep, spherical, polygonal, perenchymatus with numerous chloroplasts. Endodermis made up of single layer of cells, separated cortex from the underlying vascular tissue. Pericycle is immediately below endodermis, which is made of few parenchymatous layers of cells. Primary phloem cells were crushed and crumpled; secondary phloem forms the next zone, a complete ring of few cells. Cambium separates phloem from the xylem, about 2-3 cells deep. Metaxylem is composed of tracheids, vessels, fiber tracheids and parenchyma; protoxylem groups near pith. Vascular bundles are conjoint, collateral, endarch and open. Pith is parenchymatous (Figure 2B).

In $T$. decandra, epidermal peel renanculaceous stomata with irregular shaped epidermal cells and rosette type crystals were noticed (Figure 3A). Anatomical section is almost circular in outline where epidermis is covered by thin cuticle. Trichomes usually unicellular but sometimes two-celled. Cortex collenchymatous 8-10 cells broad; rosette type crystals were found both in cortical as well as medullary region (Figure 3B). Endodermis well developed. Vessels were either solitary or in radial rows of 3 to 7 . Vascular bundles are conjoint, collateral, endarch and open. The fasicular cambium is active and is restricted to the vascular bundles only. This results into a little amount of secondary growth within these vascular bundles. Cambium produces a new ring of vascular bundles on its inner side. These secondary bundles remain embedded in the conjunctive tissue around the pith. Pith is well developed and parenchymatous (Figure 3C).

\section{Physicochemical}

G. pharnaceoides physicochemical parameters were given in Table 1. Dried powder of the plant gives distinct color in day light on treatment with different chemicals (Table 2). Fluorescent analysis of the plant is given in Table 3. Powder of the plant is light green in color with a characteristic odor. In powder microscopy of whole plant, oval shaped calcium oxalate crystals can be used as markers (Figure 1D). The vessel elements are wide cylindrical cells with opening at the ends known as "Perforation plates" and have lateral walls with reticulate thickening (Figure 1E). Suberized vessels with narrow ends are also seen.

S. pauciflorum ash and extractive values were given in Table 1. Various specific colors were recorded with different chemical treatments (Table 2). The fluorescent analysis of the plants was given in Table 3 . Dried powder is reddish brown in color and odorless. Numerous fragments of xylem vessel elements isolated or in groups with spiral to reticulated thickening were observed. Trachieds are with bordered pits (Figure 2C). Thin patches of the polygonal or somewhat rounded suberized, parenchymatous cells; unlignified hairs with smooth and striated walls are also very prominent. Oxalate crystals are seen (Figure 2D).

T. decandra ash and extractive values were given in Table 1. Dried powder of T. decandra showed frothing after 5 min on treatment with conc. $\mathrm{H}_{2} \mathrm{SO}_{4}$. Specific colors with different chemical treatment are presented in Table 2. Fluorescence analysis of sequential extracts is given in Table 3. Dried plant powder is yellowish green, showed presence of starch grains. Rosette crystal of calcium oxalate (Figure 3D) and crystal idioblasts were also present but comparatively lesser in number (Figure 3E). Epidermal cells are with paracytic and anisocytic stomata, unicellular balloon shaped multicellular, unistriate trichomes. Trachieds and vessels with spirals sclariform and reticulate secondary wall thickening were also seen (Figures 3F, 3G).

Table 1. Physicochemical parameters of the three medicinally important arid zone plants: Gisekia pharnaceoides L., Gisekiaceae, Sericostoma pauciflorum Stocks ex Wight, Boraginaceae, and Trianthema decandra L., Aizoaceae.

\begin{tabular}{lccc}
\hline \multirow{2}{*}{ Parameters } & \multicolumn{3}{c}{ Values \% (w/w) } \\
\cline { 2 - 4 } & G. pharnaceoides & S. pauciflorum & T. decandra \\
\hline Total ash (TA) & 12.33 & 8.66 & 16.33 \\
$\begin{array}{l}\text { Acid insoluble } \\
\text { ash (AIA) }\end{array}$ & 0.66 & 1.00 & 3.33 \\
$\begin{array}{l}\text { Alcohol-soluble } \\
\text { extractive (ASE) }\end{array}$ & 1.60 & 3.20 & 4.00 \\
$\begin{array}{l}\text { Water-soluble } \\
\text { extractive (WSE) }\end{array}$ & 9.60 & 8.00 & 4.00 \\
$\begin{array}{l}\text { Loss on drying } \\
\text { (LOD) }\end{array}$ & 9.00 & 19.60 & 19.40 \\
\hline
\end{tabular}




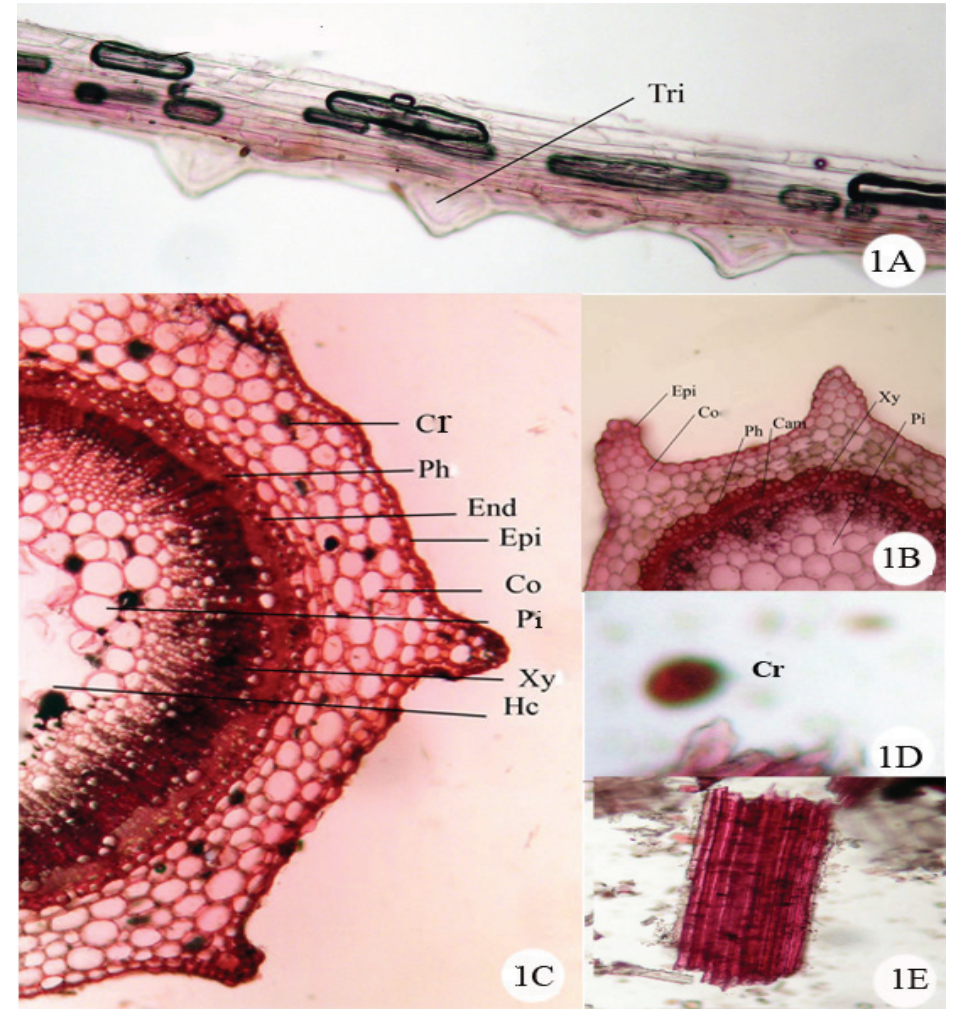

Figure 1. Microscopic and physicochemical markers of Gisekia pharnaceoides L., Gisekiaceae. 1A. Epidermal peel (40x); 1B. TS of young stem (40x); 1C. TS of mature stem (40x); 1D. Crystal idioblast; 1E. Tracheid fibers; Tri: trichomes; Epi: epidermis; Co: cortex; End: endodermis: Ph: phloem; Cam: cambium; Xy: xylem; Pi: pith; Hc: hollow cavity; Cr: Crystal idioblast.

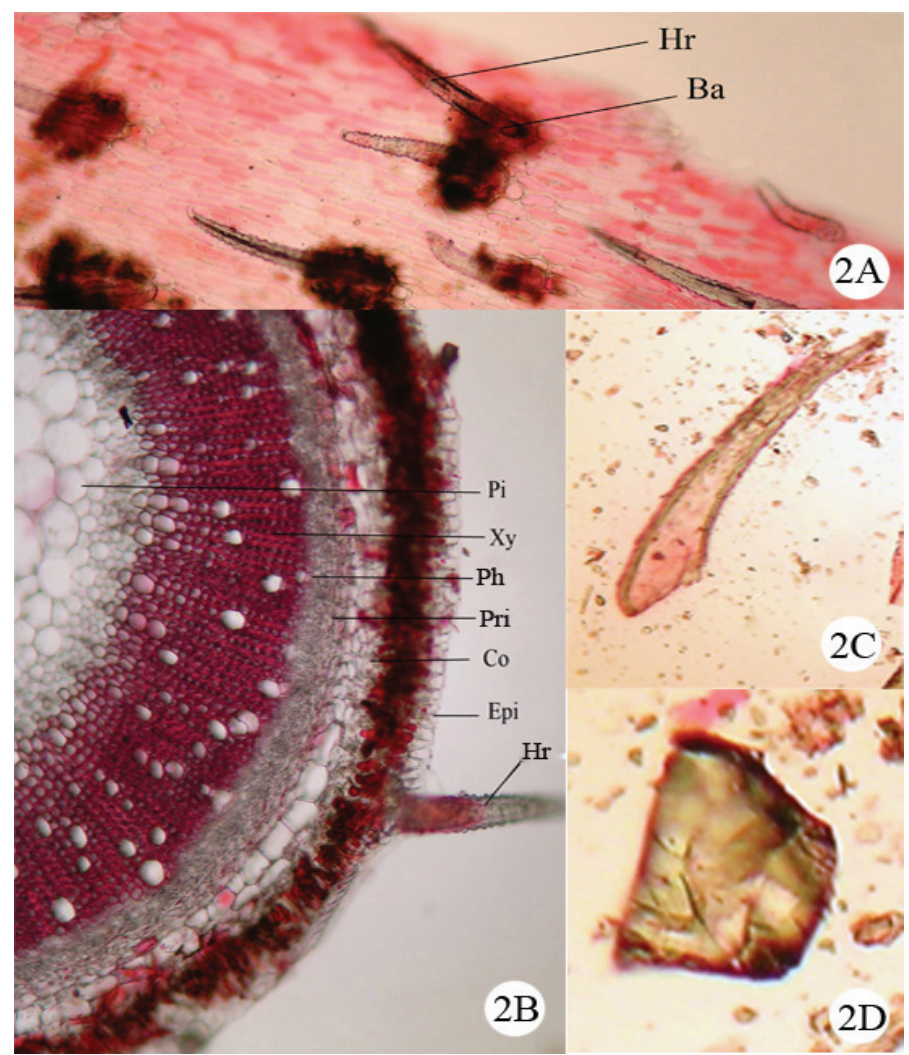

Figure 2. Microscopic and physicochemical markers of Sericostoma pauciflorum Stocks ex Wight, Boraginaceae. 2A Epidermal peel (40x); 2B. TS of stem (40x); 2C Tracheid fiber; 2D. Prism of oxalate crystal. Hr: hairs; Ba: bulbous base; Epi: epidermis; Co: cortex; Ph: phloem; Pri: pericycle; Xy: xylem; Pi: pith. 
Table 2. Powder behaviour of the three medicinally important arid zone plants after treatment with different chemical reagents: Gisekia pharnaceoides L., Gisekiaceae, Sericostoma pauciflorum Stocks ex Wight, Boraginaceae, and Trianthema decandra L., Aizoaceae.

\begin{tabular}{lccc}
\hline Treatment & G. pharnaceoides & S. pauciflorum & T. decandra \\
\hline Conc. $\mathrm{H}_{2} \mathrm{SO}_{4}$ & Golden yellow & Dark yellow & Light yellow \\
Acetic acid & Light green & Light yellow & Dark green \\
$5 \% \mathrm{I}_{2}$ solution & Light green & Light green & Light green \\
$5 \% \mathrm{FeCl}_{3}$ solution & Yellowish green & Dark yellowish green & Yellow green \\
$\mathrm{Few} \mathrm{drops} \mathrm{of} \mathrm{dil.} \mathrm{NH}_{3}+\mathrm{K}_{4} \mathrm{Fe}(\mathrm{CN})_{6}$ solution & Green & Light green & Light green \\
$10 \% \mathrm{NaOH}$ followed by a drop of $\mathrm{CuSO}_{4}$ & Green & Light green & Blue green \\
$40 \% \mathrm{NaOH}+$ few drops of $10 \%$ lead acetate & Greenish milky white & Yellowish milky white & Milky white \\
Acetic acid + Conc. $\mathrm{H}_{2} \mathrm{SO}_{4}$ & Light reddish green & Dark reddish green & Light reddish green \\
Conc. $\mathrm{HNO}+$ excess of $\mathrm{NH}_{3}$ & Brown & Dark brown & Brown \\
Acetic acid + a trace of $\mathrm{FeCl}_{3}$ and transferred to & Reddish green & Dark green & Dark reddish green \\
the surface of conc. $\mathrm{H}_{2} \mathrm{SO}_{4}$ & & \\
\hline
\end{tabular}

Table 3. Fluorescence analysis of sequential extracts of three medicinally important arid zone plants.

\begin{tabular}{|c|c|c|c|c|}
\hline Plant species & Extracts & Day light & UV light (254 nm) & UV light (365nm) \\
\hline \multirow{4}{*}{ Gisekia pharnaceoides L., Gisekiaceae } & Pet ether & Dark green & Dark green & Brown \\
\hline & Dichloromethane & Dark green & Light green & Brownish green \\
\hline & Ethyl acetate & Brownish green & Dark green & Brown \\
\hline & Methanol & Brown & Green & Dark green \\
\hline \multirow{5}{*}{$\begin{array}{l}\text { Sericostoma pauciflorum Stocks ex Wight, } \\
\text { Boraginaceae }\end{array}$} & Pet ether & Brown & Dark green & Brown green \\
\hline & Dichloromethane & Brown green & Brown green & Dark brown \\
\hline & Ethyl acetate & Olive green & Dark green & Brown green \\
\hline & Methanol & Olive green & Dark green & Brown \\
\hline & Water & Dusty green & Green & Brown \\
\hline \multirow{5}{*}{ Trianthema decandra L., Aizoaceae } & Pet ether & Green & Golden green & Brown \\
\hline & Dichloromethane & Brown green & Golden green & Golden brown \\
\hline & Ethyl acetate & Dark green & Golden green & Brown \\
\hline & Methanol & Light brown & Green & Dark brown \\
\hline & Water & Brown & Light green & Light brown \\
\hline
\end{tabular}

Table 4. Preliminary phytochemical analysis of three medicinally important arid zone plants.

\begin{tabular}{|c|c|c|c|c|c|c|c|}
\hline Plant species & Extracts & Proteins & Carbohydrates & Flavonoids & Triterpenoids & Tannins & Alkaloids \\
\hline \multirow{4}{*}{$\begin{array}{l}\text { Gisekia pharnaceoides L., } \\
\text { Gisekiaceae }\end{array}$} & Pet ether & - & + & - & +++ & + & + \\
\hline & Dichloromethane & - & - & - & ++ & - & - \\
\hline & Ethyl acetate & - & - & ++ & - & ++ & + \\
\hline & Methanol & ++ & + & + & - & ++ & + \\
\hline \multirow{5}{*}{$\begin{array}{l}\text { Sericostoma pauciflorum } \\
\text { Stocks ex Wight, } \\
\text { Boraginaceae }\end{array}$} & Pet ether & - & - & + & +++ & - & - \\
\hline & Dichloromethane & - & - & + & ++ & - & - \\
\hline & Ethyl acetate & - & - & +++ & - & + & + \\
\hline & Methanol & ++ & + & + & - & +++ & ++ \\
\hline & Water & + & ++ & + & - & + & + \\
\hline \multirow{4}{*}{$\begin{array}{l}\text { Trianthema decandra L., } \\
\text { Aizoaceae }\end{array}$} & Pet ether & - & - & - & + & - & - \\
\hline & Ethyl acetate & - & - & ++ & ++ & ++ & - \\
\hline & Methanol & + & ++ & - & - & +++ & ++ \\
\hline & Water & + & + & + & - & + & + \\
\hline
\end{tabular}

+ Denotes the presence of the respective class of compounds where + shows low, ++ moderate, +++ high and - absence of respective secondary metabolites. 


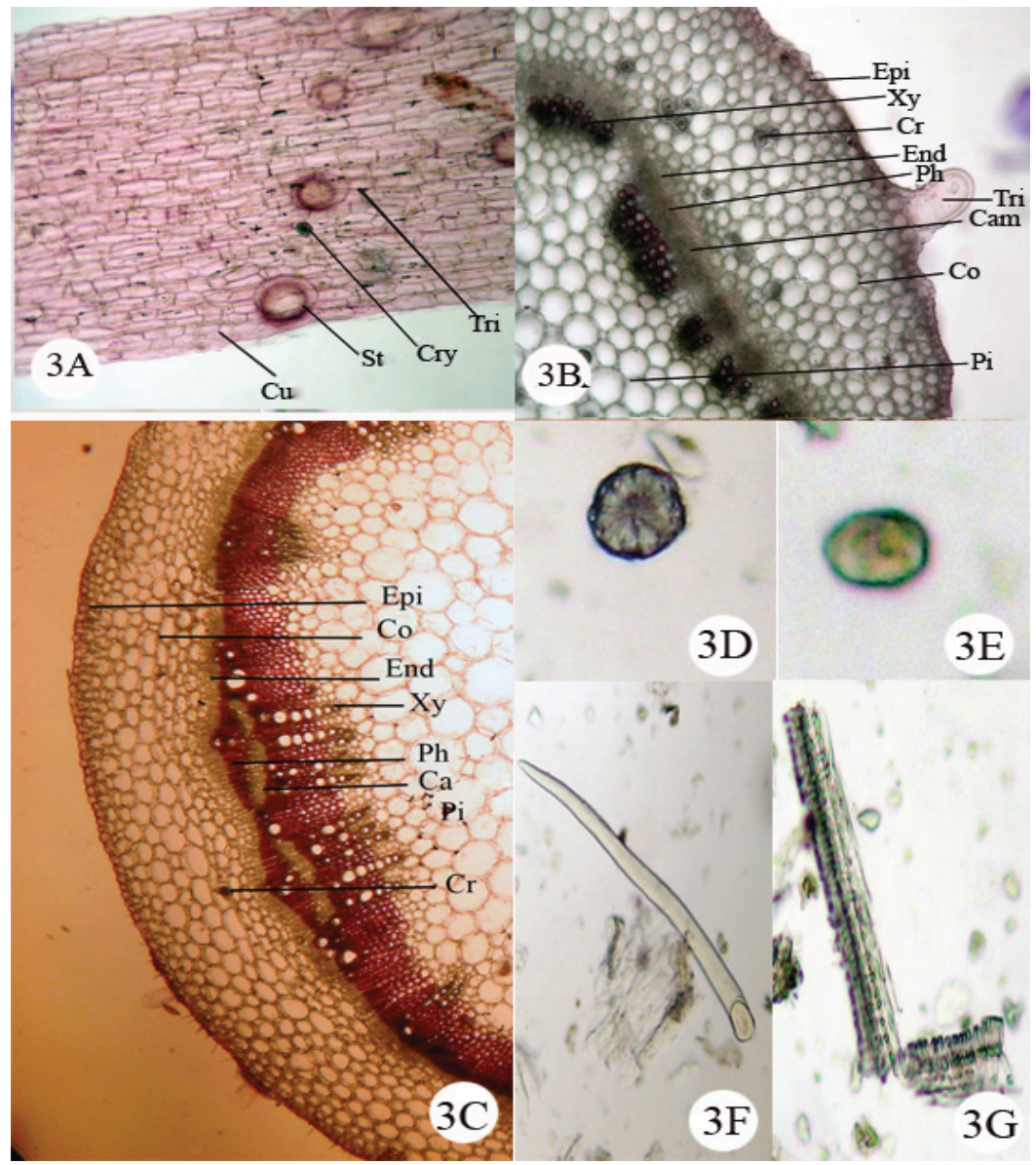

Figure 3. Microscopic and physicochemical markers of Trianthema decandra L., Aizoaceae. 3A. Epidermal peel (40 x); $3 \mathrm{~B}$. TS of younger stem (40x); 3C. TS of older stem (40x); 3D. Rosette type crystals; 3E. Oval shaped crystals; 3F. Warty trichome; 3G. Vessel element with reticulate lateral wall pits. St: stomata; Tri: trichome; $\mathrm{Cu}$ : cuticle; Epi: epidermis; Co: cortex; End: endodermis; Ph: phloem; Ca: cambium; Xy: xylem; Pi: pith; Cr: crystal.

\section{Phytochemical}

Preliminary phytochemical tests exhibited the presence of different metabolites such as proteins, carbohydrates, triterpenoids, flavonoids, tannins and alkaloids in different concentration (Table 4).

The quantitative determination of some pharmacognostical parameters is useful for setting standards for crude drugs. Total ash value and acidinsoluble ash value determination is equally important in the evaluation of crude drugs. The total ash is particularly important in the evaluation of purity of drugs, i.e. the presence or absence of foreign inorganic matter such as metallic salts and/or silica (Harborne, 1998).

In the selected plant species, a comparison of physicochemical markers revealed that the order of TA is $T$. decandra $>G$. pharnaceoides $>S$. pauciflorum and in case of AIA $T$. decandra $>S$. pauciflorum $>G$. pharnaceoides. WSE present in highest amount in $G$. pharnaceoides and lowest in $T$. decandra while LOD values are highest in $S$. pauciflorum and lowest in $G$. pharnaceoides.
In phytochemical analysis, higher levels of protein in methanol fraction of $G$. pharnaceoides and $S$. pauciflorum, carbohydrates in water fraction of $S$. pauciflorum and methanol fraction of $T$. decandra, flavonoids in ethyl acetate fraction of $S$. pauciflorum; triterpenoids in pet ether fraction of $G$. pharnaceoides and $S$. pauciflorum tannins in methanol fraction of $S$. pauciflorum and T. decandra and alkaloids in methanol fractions of $S$. pauciflarum and $T$. decandra are reported. Different test samples showed varied colors after chemical and fluorescence analyses. Comparative anatomy is helpful in the identification of plant material(s) in its fragmentary or partly decomposed condition. Among these plants, T. decandra showed abnormal secondary growth (Metcalfe \& Chalk, 1950) with numerous vascular bundles arranged in distinct concentric rings and complete alternating rings of xylem and phloem one after the other.

Thus, ethnobotanical studies have conducted on the selected traditional plants of arid zone, viz. $G$. pharnaceoides, S. pauciflorum and T. decandra have their morphological (macroscopic), anatomical (microscopic), physicochemical and phytochemical markers. 


\section{ACKNOWLEDGEMENT}

Authors are thankful to the Indian Council of Medical Research (ICMR), New Delhi, India for financial support.

\section{REFERENCES}

Afza N, Bader A, Malik A, Ayatollahi AM, Ahmad Z, Khan AQ 1992. Structural studies of triterpenoid isolated from some Euphorbia species and Sericostoma pauciflorum. Proc $1^{\text {st }}$ Int Conference Pharm Sci, p. 39-56.

Amico A 1977. Medicinal plants of Southern Zambesia. Fitoterapia 48: 101-139.

Ayatollahi AM, Ahmad Z, Malik A 1991. Fernane-type triterpene from Sericostoma pauciflorum. J Nat Prod 54: 570-572.

Ayatollahi SAM, Ahmad Z, Afza N, Malik A 1992a. A triterpene from Sericostoma pauciflorum. Phytochemistry 31: 2899-2901.

Ayatollahi SAM, Ahmad Z, Malik A, Afza N, Bader A 1992b. Hopane type triterpenoid from Sericostoma pauciflorum. Fitoterapia LXIII: 304-307.

Bakshi DN, Sensharma P, Pal DC 2001. A Lexicon of Medicinal Plants in India. Naya Prakash, Calcutta, pp. 258.

Brain KR, Turner TD 1972. In: The Practical Evaluation of Phytopharmaceuticals, Wright-Scietechnica, Bristol, p. 4-9.

Chase CR, Pratt RJ 1949. Fluorescence analysis of powdered vegetable drugs with particular reference to development of a system of identification, $\mathrm{J} \mathrm{Am}$ Pharmacol Assoc 38: 324-331.

Chopra RN, Nayar RN, Chopra IC 1956. Glossary of Indian Medicinal Plants, CSIR, New Delhi, pp. 125.

Harborne JB 1998. Methods of extraction and isolation, In: Phytochemical Methods, Chapman \& Hall, London, p. 60-66.

Indian Pharmacopoeia 1996. $4^{\text {th }}$ ed., Vol. II, Government of India, Ministry of Health and Welfare, New Delhi, A48A54.

Iyer A, Pant UC, Joshi BC 1972. Chemical investigation of Gisekia pharnaceoides. Phytochemistry 11: 2883-2884.

Johansen DA 1940. Plant Microtechniques. McGraw Hill Book Company, Inc. New York, pp. 27-94.

Kokate CK 1986. Practical Pharmacognosy, $1^{\text {st }}$ ed., Vallabh Prakashan, New Delhi, pp. 112-120.

Kokoshi J, Kokoski R, Slama FJ 1958. Fluorescence analysis of powdered vegetable drugs under ultraviolet radiation, $J$ Am Pharmaco Assoc 47: 75-77.

Metcalfe CR, Chalk L 1950. Anatomy of the Dicotyledons. Vol I. Clarendon Press, Oxford, pp. 654.

Musa KY, Katsayal AU, Ahmed A, Mohammed Z, Danmalam UH 2006. Pharmacognostic investigation of the leaves of Gisekia pharnaceoides. African J Biotech 5: 956957.

WHO/PHARM/92.55/rev. 1992. Quality Control Methods for Medicinal Plants Materials, Organisation Modiale De La Sante, Geneva, p. 22-34. 